\title{
UPRAVLJANJE RIZICIMA POSLOVANJA ODABRANIH PODUZEĆA METALOPRERAĐIVAČKE DJELATNOSTI U VRIJEME PANDEMIJE
}

\author{
Mr. sc. Željko Tintor \\ RETRA d.o.o. za reviziju i poslovno savjetovanje \\ Lastovska 6., 10000 Zagreb, Hrvatska \\ Telefon: +385 916159 292, e-mail: retra@zg.htnet.hr
}

\section{SAŽETAK}

Najznačajnija zadaća menadžmenta jest donošenje poslovnih odluka kojima je cilj osigurati optimalno poslovanje i ostvarivanje dobiti te budući rast i razvoj poduzeća. Za to je nužno organizirati sustav praćenja kojim će se pravovremeno identificirati rizici koji mogu utjecati na poslovanje poduzeća i donošenje poslovnih odluka. Stoga je iznimno važno pažnju posvetiti analizi poslovanja i razvoju sustava upravljanja rizicima primjerenim tržišnim $i$ društvenim promjenama. Proteklu, 2020. godinu, pored stalnih tržišnih izazova, posebno je obilježila pojava globalne pandemije uzrokovane virusom COVID-19, a koja je značajno utjecala na promjene ukupnog društvenog i gospodarskog života u svijetu i u našoj zemlji. Povećana je nezaposlenost, a smanjeni prihodi, potražnja, ponuda i proizvodnja. Radi sprječavanja širenja virusa s nepredvidljivim zdravstvenim i ekonomskim posljedicama, većina država u svijetu, a posebice zemlje Europske zajednice, uključivo i naša država, donijele su različite sigurnosne mjere s ciljem socijalnog distanciranja, od onih blažih $i$ preporučenih do zabrana kretanja (lockdown) građana. Ukidana su iliograničavana kretanja građana na lokalnoj razini te putovanja među gradovima i državama, ograničavan je rad trgovina i zabranjivano poslovanje pojedinih djelatnosti, a odlazak na posao zamijenjen je radom od kuće i reorganizacijama radnog vremena. Sve to je imalo negativan utjecaj na ekonomiju, posebice na turizam, ugostiteljstvo, transport i trgovinu, ali i na proizvodne djelatnosti, ovisno o tome u kojoj su mjeri ovisni o širokoj, industrijskoj ili investicijskoj potrošnji, odnosno lokalnom, nacionalnom ili međunarodnom tržištu. Metaloprerađivačka djelatnost ima dugogodišnju tradiciju i s oko 20 \% udjela u društvenom proizvodu i oko $25 \%$ udjela u izvozu čini značajnu pokretačku snagu gospodarstva Hrvatske. Zato je ovaj rad posvećen istraživanju utjecaja globalne pandemije na poslovanje odabranih poduzeća metaloprerađivačke industrije u Republici Hrvatskoj. Analizirano je poslovanje triju poduzeća kojima je zajednička djelatnost i poslovanje na domaćem i inozemnom tržištu, a različiti su im veličina i pravni status. Problem istraživanja bio je prepoznati rizike poslovanja odabranih poduzeća u uvjetima pandemije, što je učinjeno komparativnom financijskom analizom u pandemijskoj 2020. godini prema 2019. godini u kojoj nije bilo pandemije. Cilj istraživanja jest procjena utjecaja pandemije na njihovo poslovanje kroz financijske pokazatelje i modele upravljanja rizicima poslovanja u uvjetima pandemije. Opća je ocjena da će se negativan utjecaj pandemije nastaviti i u narednom razdoblju, 
stoga smo značajnu pozornost u radu posvetili i procjenama budućih kretanja i razvoju sustava upravljanja rizicima.

Ključne riječi: upravljanje rizicima poslovanja, globalna pandemija, metaloprerađivači, financijska analiza

\section{UVOD}

Polaznu osnovu u izučavanju ove problematike čini pretpostavka da je poduzeće poslovnofinancijski sustav u kojem menadžeri svakodnevno donose odluke kojima utječu na pribavljanje, kretanje i alokaciju sredstava poduzeća. Pri tome su tokovi sredstava usmjereni prema investicijama, poslovanju i financiranju, a odluke kojima se oni usmjeravaju obuhvaćaju investicijske odluke, odluke o poslovanju i odluke o financiranju. Investicijske odluke su ključne jer se njima pokreće poslovanje i omogućuje provedba strategije razvoja. One uključuju usmjeravanje postojećih i/ili pribavljenih kapitalnih sredstava za ulaganje u: (1) dugotrajnu imovinu koja čini infrastrukturu nužnu za poslovanje, (2) obrtni kapital potreban za tekuće poslovanje i (3) istraživanja i razvoj novih proizvoda, tržišta i sl. Odluke o poslovanju usmjerene su na politiku prihoda i na djelotvornu kontrolu i optimalizaciju troškova poslovanja. Odluke o financiranju podrazumijevaju poslovne odluke o korištenju neto dobiti, odnosno na njezinu podjelu između vlasnika, vjerovnika i zadržavanja za potrebe investiranja, dok odluke o strukturiranju kapitala poduzeća imaju za cilj osigurati primjeren vlasnički kapital i optimizirati omjer sredstava iz vlastitih izvora, tj. uloženog i zarađenog kapitala i tuđih dugoročnih izvora. Svaka od navedenih skupina upravljačkih odluka zasniva se na određenom konceptu informacija dobivenih analizom financijskih izvještaja, ali i određenih tržišnih i ostalih informacija, a zajednički promatrano sve su usmjerene na upravljanje rizicima poslovanja poduzeća. Cilj i izazov ovog rada jest prepoznati koji su se rizici poslovanja dodatno pojavili s globalnom pandemijom te kojim odlukama i mjerama, odnosno uspjehom su poduzetnici upravljali rizicima poslovanja odabranih poduzeća metaloprerađivačke djelatnosti. Pri tome ne treba gubiti iz vida činjenicu da je cjelokupno gospodarstvo, uključujući i metaloprerađivačku djelatnost, u vrijeme pandemije imalo veće ili manje zastoje u radu, pad proizvodnje, gubitke, pa čak i stečajeve. Polazne osnove rada su da je analiza financijskih izvještaja usmjerena na ispitivanje vrijednosnih podataka prikazanih u financijskim izvještajima, da su interpretacija podataka i informacije dobivene financijskom analizom u funkciji donošenja upravljačkih odluka, da se kombinacijom financijskih i nefinancijskih informacija može osigurati upravljanje rizicima poslovanja i u vrijeme izvanrednog stanja poput globalne pandemije te da upravljanjem rizicima poslovanja svaka kriza može biti i poslovna šansa poduzetnika. Primarno istraživanje autora obuhvaća analizu financijskih izvještaja odabranih poduzetnika i određenih nefinancijskih tržišnih informacija, dok su sekundarna istraživanja obuhvatila relevantnu znanstvenu i stručnu literaturu za postavljanje okvira istraživanja. Metode rada obuhvaćaju primjenu analitičkih metoda i tehnika, a dobiveni rezultati su komparativno prikazani u prezentiranim tablicama s komentarima i zaključcima. 


\section{RIZICI POSLOVANJA}

Svaki poduzetnički projekt nosi određene rizike poslovanja, a poduzetnik bi trebao koristeći svoja iskustva, znanja, poznavanje okruženja ili pak uz pomoć suvremenih metoda procjena rizika nastojati rizik poslovanja svesti na što manju mjeru, odnosno nepredvidive utjecaje pretvoriti u predvidive kako bi mogao upravljati rizicima poslovanja. Općenito, rizik poslovanja se prvenstveno odnosi na mogućnost financijskog gubitka, ali podrazumijeva i negativna odstupanja od planiranih veličina, koja u budućem razdoblju mogu rezultirati neizvjesnim ishodom i financijskim gubicima. Rizik poslovanja možemo promatrati kao temeljni rizik, dakle rizik koji pod utjecajem vanjskih ekonomskih, političkih, društvenih ili prirodnih pojava zahvaća sve razine, dijelove i procese u poduzeću. U našem slučaju je riječ upravo o toj vrsti rizika poslovanja uvjetovanog općom pandemijom. Međutim, postoje i druge vrste rizika poslovanja, poput čistog rizika poslovanja, koji karakterizira besperspektivna situacija i mogućnost napretka ili promjena restrukturiranjem i sl. Konačno, postoje i špekulativni rizici poslovanja koji su umjetno izazvani s ciljem utjecaja na određene buduće poslovne tokove koji bi trebali rezultirati dobiti ili gubicima, ovisno od interesa subjekta koji upravlja rizicima poslovanja. Operativnim rizicima najčešće podrazumijevamo rizike likvidnosti i stabilnosti, zaduženosti, profitabilnosti i ekonomičnosti, investicijske rizike te nemogućnosti vremenske neograničenosti poslovanja.

\section{RIZICI GLOBALNE PANDEMIJE BOLESTI COVID-19}

Krajem 2019. svijet se susreće s pojavom bolesti COVID-19. Značajna karakteristika virusa je bila visoki reprodukcijski broj transmisije, odnosno brzo širenje virusa izvan granica njegove inicijalne pojave. Početkom 2020. godine pandemija u većoj ili manjoj mjeri zahvaća gotovo sve zemlje u svijetu. Mogli bismo konstatirati da je u toj prvoj fazi pojave pandemije zavladala opća konsternacija, čak i kod gospodarski najrazvijenijih zemalja, jer je, uz izostanak jedinstvenog tumačenja sadržaja i opasnosti virusa od strane stručnjaka i vodećih političara, još veća konsternacija zavladala kod stanovništva, od odbijanja suočavanja s opasnošću bolesti do inzistiranja za poduzimanjem radikalnih mjera kako bi se spriječilo širenje bolesti i smrtnost koja je postajala sve veća. U mnogim zemljama, unatoč visokom stupnju ekonomske razvijenosti i organiziranosti društava, odjednom su vlasti postale svjesne da ne raspolažu resursima za preventivno djelovanje. Svaka je država donosila određene zaštitne mjere na pretpostavkama o utjecaju i posljedicama virusa, koji je već u ranoj fazi razvoja pokazao svu svoju nepredvidljivost u pogledu načina širenja, različitog stupnja utjecaja i opasnosti po generacijama građana te mogućoj efikasnosti pojedinih lijekova. Postupno se dolazi do određenih spoznaja pa sve zemlje svoje mjere upućuju u dva pravca. Prvi je socijalno distanciranje ograničavanjem kretanja i zatvaranjem mjesta okupljanja stanovništva radi sprječavanja širenja virusa, a drugi je usmjeren ka ekonomskim kompenzacijama gubitaka, kako ne bi došlo do otpuštanja zaposlenika i masovnih stečajeva. 
Ne ulazeći u kronologiju i detalje svih tih mjera koje su u svakoj zemlji imale različit sadržaj i intenzitet, zemlje EU, unatoč nastojanjima, nisu uspjele održavati jedinstveni pristup rješavanju problema - od procijepljenosti stanovništva koje se u pojedinim zemljama suočavalo s masovnim protestima i otporima do ekonomskim mjera koje su u konačnici ovisile o realnim financijskim mogućnostima svake pojedine zemlje. Obveza socijalnog distanciranja praćena ograničavanjima kretanja stvarala je svakodnevne probleme građanima pri snabdijevanju nužnim životnim namirnicama, u nemogućnosti ostvarivanja poslovnih, kulturnih i drugih sadržaja i sl. Lockdown s ograničenjem kretanja, djelomičnim i/ili potpunim radom od kuće, skraćivanjem radnog vremena i gubicima zaposlenja za veliki broj ljudi i poduzeća zahtijeva uvođenje novog stila života i poslovnih promjena kako bi se stvorila neka vrsta prilagodbe stanju i rizicima globalne pandemije.

Teške sociopsihološke posljedice, koje će se vjerojatno još dugi niz godina odražavati na život i ponašanje građana, imale su i svoj utjecaj na ekonomiju. Razvija se posebni oblik ekonomske krize. Za razliku od prijašnjih recesija i depresija kojima su izvorišta bila uglavnom u financijskim i/ili gospodarskim sustavima, pa su i rizici upravljanja poslovanjem bile usmjeravani u tom pravcu, globalna pandemija sa socijalnom distancom donosi teške sociopsihološke probleme koji zaustavljaju sve gospodarske i financijske tokove. Tako, primjerice, razvijene industrije su mogle održavati neke proizvodnje samo dok su trajale postojeće zalihe sirovina i rezervnih dijelova jer novih zaliha zatvaranjem transporta nije bilo ili pak njihovi kooperanti iz drugih zemalja nisu imali uvjete za bilo kakvo poslovanje. Zbog toga na ekonomskom planu možemo govoriti o tome da je globalna pandemija, osim poremećaja ponude i potražnje i pada BDP-a, u većini zemalja uvjetovala i dugoročne neizvjesnosti i negativna očekivanja. Nagli pad zaposlenosti i zakašnjele vladine odluke nisu bile dostatne za životno funkcioniranje pa je tako globalna pandemija utjecala na smanjenje prihoda i poduzeća i pojedinaca, što je imalo negativan utjecaj na funkcioniranje ekonomije i financijska tržišta.

\section{MODELI UPRAVLJANJA RIZICIMA}

Upravljati rizicima znači prvenstveno identificirati rizike poslovanja, procijeniti njihove utjecaje na poslovanje i poduzeti određene mjere za rješavanje rizika poslovanja. Zato procesu izgradnje modela upravljanja rizicima prethodi nekoliko faza: (1) identifikacija rizika koja podrazumijeva utvrđivanje vrste rizika poslovanja, (2) analiza rizika koja podrazumijeva utvrđivanje njegova sadržaja i složenosti, (3) procjena, odnosno vrednovanje utjecaja rizika na poslovanje, (4) rješavanje rizika, što podrazumijeva odabir strategije, modela i alata za rješavanje rizika poslovanja i (5) nadziranje rizika tijekom njegova rješavanja i usmjeravanja rješenja prema trajnom otklanjanju uzroka rizika poslovanja.

Modeli upravljanja rizicima mogu biti različiti. U literaturi se danas često navodi nekoliko razvijenih i patentiranih modela upravljanja rizicima poslovanja, poput Enterprise Risk Management (ERM), Loss Control Management (LCM), ali postoje i drugi. Za razliku od LCM metode kojom se nastoji utjecati na smanjenje mogućnosti stvaranja gubitaka i njihova utjecaja na smanjenje mogućnosti daljnjeg poslovanja, ERM je metoda kojom se identificiraju i procjenjuju rizici, istražuju organizacijska struktura i uzroci te razvijaju strategija, instrumenti, metodologija i sustavi upravljanja financiranja i nadzora, kako bi se buduća vrijednost poduzeća dugoročno povećala. Primjereno složenosti uzroka rizika 
poslovanja, u domaćoj se praksi primjenjuju i neke jednostavnije metode sa specifičnim korištenjem raspoloživih resursa. Međutim, bez obzira na korištene metode upravljanja rizicima, svima je zajednička nužnost poznavanja i razumijevanja problematike, poznavanje unutarnjeg i vanjskog okruženja kao izvora rizika poslovanja te korištenje analitičkih metoda istraživanja i izvještavanja o načinu upravljanja rizicima poslovanja te posebice znanje i vještine onih koji upravljaju rizicima.

\section{PRIKAZ ODABRANIH PODUZEĆA}

Ovaj je rad posvećen istraživanju utjecaja globalne pandemije na poslovanje odabranih poduzeća metaloprerađivačke industrije u Republici Hrvatskoj. Na opredjeljenje za istraživanjem u toj djelatnosti utjecala je činjenica da ista ima dugogodišnju tradiciju te da s oko 20 \% udjela u društvenom proizvodu i oko $25 \%$ udjela u izvozu čini značajnu pokretačku snagu gospodarstva Hrvatske. Analizirano je poslovanje triju poduzeća, kojima je zajednička djelatnost i poslovanje na domaćem i inozemnom tržištu, a različita im je veličina i pravni status. Problem i zadaća istraživanja bila je prepoznati rizike poslovanja odabranih poduzeća u uvjetima pandemije. U njihovu predstavljanju uvjetno ćemo koristiti nazive poduzeća A, B i C, a za što bolje razumijevanje pojasnit ćemo veličinu, djelatnost, asortiman, tržišnu orijentaciju, misiju i viziju, kao i druge značajke njihova poslovanja.

Poduzeće A prema nomenklaturi pripada velikim trgovačkim društvima. Organizirano je kao društvo s ograničenom odgovornošću i malim brojem suvlasnika. Društvo zapošljava više od 1500 ljudi. Bavi se namjenskom proizvodnjom, a svoje proizvode uglavnom izvozi na tržište SAD-a, potom zemlje EU, treće zemlje, dok se samo manji dio proizvodnje orijentira na domaće tržište. Riječ je o visokoserijskoj proizvodnji. Primjenjuje najsuvremeniju tehnologiju u djelatnosti. Ulaže u nove proizvode i inovativnu tehnologiju. U proizvodnji koristi vlastiti zaokruženi proizvodni sustav. $90 \%$ prihoda dolazi od izvoza, dok preostalih $10 \%$ čini prodaja na domaćem tržištu.

Poduzeće B prema nomenklaturi pripada srednje velikim trgovačkim društvima. lako je formalno-pravni status poduzeća dioničko društvo, zapravo se radi o obiteljskom poduzeću. Društvo zapošljava oko 250 ljudi. Bavi se specifičnom proizvodnjom lijevanih željeznih proizvoda namijenjenih cestovnoj i prvenstveno lokalnoj komunalnoj infrastrukturi. Svoje proizvode izvozi u zemlje okruženja i zemlje EU, a zastupljenost izvoza je oko $60 \%$, dok preostalih 40 \% čini prodaja na domaćem tržištu. Uz osnovnu razvija se i sporedna proizvodnja toplinskih peći. Specifičnost proizvodnje ne zahtijeva visoku sofisticiranu tehnologiju, mada istraživanjima nastoji djelatnost proširiti prema automobilskoj industriji.

Poduzeće $\mathbf{C}$ prema nomenklaturi pripada malom trgovačkom društvu. Organizirano je kao obiteljsko društvo s ograničenom odgovornosti. Zapošljava oko 50 ljudi. Bavi se uslužnom proizvodnjom, točnije laserskom obradom svih vrsta metala i u kategoriji je visokotehnoloških tvrtki. Koristi najsuvremeniju tehnologiju za tu vrstu djelatnosti. Domaće tržište postupno kompenzira sve većim izvozom u zemlje EU. Zastupljenost izvoza je oko 40 \%, dok ostatak čini domaće tržište. Specifičnost proizvodnje sadržana je u činjenici da, osim serijske, ima mogućnost pojedinačne proizvodnje svih vrsta metalnih proizvoda i modela. Raspolaže projektnim centrom za vlastite i tuđe potrebe. 


\section{IZVORI INFORMACIJA}

Da bismo mogli osigurati pravodobno i kvalitetno odlučivanje menadžera i drugih zainteresiranih skupina, potrebno je posegnuti za izvorima informacija pomoću kojih se prate poslovanje i rezultati poslovanja, a koji nam omogućuju da primjenom analitičkih metoda i tehnika osiguramo pokazatelje koji nam pomažu u donošenju poslovnih odluka i upravljanju rizicima poslovanja. Obično je to skup javno objavljenih financijskih izvještaja sastavljenih prema propisima i računovodstvenim standardima, a koji javnosti pružaju temeljne podatke o poslovanju i rezultatima poslovanja poduzeća poduzetnika. „Financijski izvještaji služe kao kontrolna ploča s mjernim instrumentima. Oni izvještavaju o radu menadžera, potvrđuju njihove uspjehe i neuspjehe i upozoravaju na probleme. Tumačenje informacija koje daje složena kontrolna ploča zahtijeva poznavanje instrumenata i njihova prilagođavanja kako bi se razumjeli dobiveni podaci“ (Meigs \& Meigs, 1999, str. 923). Temeljne financijske izvještaje čini skup koji najčešće obuhvaća: (a) bilancu, (b) račun dobiti i gubitka, (c) izvještaj o novčanom toku, (d) izvještaj o promjenama kapitala (glavnice) i (e) bilješke uz financijske izvještaje, pripremljene u skladu s propisima i općeprihvaćenim računovodstvenim standardima, koji osiguravaju njihovu autentičnost, transparentnost i usporedivost. Sadržajno, svaki od njih daje određeni prikaz stanja i poslovanja kao rezultat prošlih upravljačkih odluka. „Svi ti izvještaji međusobno su povezani i upućeni jedni na druge. Neki su statičkog karaktera jer pokazuju situaciju u određenoj točki vremena, a drugi pokazuju promjene ekonomskih kategorija u određenom razdoblju te stoga imaju dinamički karakter. Promatrani zajedno, u međusobnoj interakciji, govore o „zdravstvenom stanju“ nekog poduzeća, a utvrditi i razumjeti to „stanje“ znači imati mogućnost donositi primjerene i racionalne poslovne odluke“ (Grupa autora, redaktor Lajoš, 2008. str. 52). Kako analize financijskih izvještaja počivaju na informacijama sadržanim u tim izvještajima, potrebno je razumjeti njihov obuhvat, značajke i ograničenja, a u svrhu ispravne interpretacije podataka i informacija dobivenih analizom financijskih izvještaja. Za potrebe ovog istraživanja, kao izvor financijskih informacija koristit ćemo bilancu i račun dobiti i gubitka odabranih metaloprerađivačkih poduzeća. Specifičnost istraživanja u ovom slučaju jest činjenica da su komparativnim analizama obuhvaćena dva razdoblja i to prvo razdoblje u godini prije pojave pandemije i drugo razdoblje u godini pandemije.

\subsection{Bilanca}

Bilanca je jedan od temeljnih financijskih izvještaja, koji pokazuje financijsko stanje poduzetnika na određeni dan. Sadržajno svojim obujmom i strukturom, bilanca obuhvaća imovinu i izvore te imovine u formi obveza i kapitala na određeni dan, redovito na kraju poslovne godine. Dakle, temeljni segmenti bilance $s$ jedne strane jesu imovina sadržana $u$ aktivi bilance te kapital i obveze sadržani u pasivi bilance, kao izvori financiranja ukupno raspoložive imovine $u$ aktivi bilance.

Aktiva bilance pokazuje sadržaj i strukturu ukupno raspoložive vlastite imovine poduzeća. Najvažnije su kategorije imovine: (a) stalna imovina koja se koristi dugoročno i (b) tekuća imovina koja se koristi kratkoročno. Kombinacijom kriterija vrste, pojavnih oblika i trajnosti, imovina kojom raspolaže poduzeće u bilančnoj aktivi prikazana je prema kriteriju rastuće likvidnosti, što znači da su na prvom mjestu prikazani vrste i oblici dugotrajne 
imovine, a potom vrste i oblici kratkotrajne imovine. U aktivi bilance dugotrajna imovina je klasificirana kao: nematerijalna imovina, materijalna imovina, financijska imovina i potraživanja, a kratkotrajna imovina se klasificira kao: zalihe, potraživanja, kratkotrajna financijska imovina i novac u banci i blagajni. Tako klasificirane kategorije imovine dalje se analitički prikazuju u podskupinama po vrstama imovine.

U pasivi bilance izvori angažirane imovine klasificirani su na: (a) kapital kao vlastite izvore imovine i obveze kao tuđe izvore imovine, s tim da su obveze raščlanjene na (b) tekuće obveze s dospijećem do godine dana i (c) dugoročne obveze koje su plative u roku duljem od godine dana. Kapital i obveze također se dalje analitički razrađuju i prikazuju u podskupinama po vrstama izvora financiranja.

Temeljna značajka bilance jest koncept dvostranog promatranja, odnosno bilančna ravnoteža imovine s jedne strane i kapitala i obveza s druge strane. Navedena ravnoteža ne govori ništa o financijskom stanju poduzetnika. Tek izučavanje njezine strukture upućuje na određena stanja poduzetnika. Primjerice, cjelokupna imovina prikazana u aktivi jest u formalno-pravnom vlasništvu poduzetnika. Međutim, samo kapital pokazuje koji je dio imovine u stvarnom vlasništvu poduzetnika, a koji je dio u tuđem vlasništvu (vjerovnici) i koliko iznose neotplaćene obveze u pasivi bilance ili pak kakav je odnos vlastitih i tuđih izvora što upućuje na stupanj zaduženosti poduzetnika. Sve su to značajna bilančna pitanja o utjecaju na upravljanje rizicima poslovanja.

\subsection{Račun dobiti i gubitka}

Račun dobiti i gubitka jedan je od temeljnih financijskih izvještaja, koji prikazuje učinke ranijih poslovnih odluka na poslovanje. Pokazuje obujam i strukturu prihoda i rashoda i dobit odnosno gubitak kao financijski rezultat njihova sučeljavanja u određenom obračunskom razdoblju, najčešće tijekom kalendarske godine.

Osnovni model u našoj praksi obuhvaća poslovne i financijske prihode s jedne strane i poslovne i financijske rashode s druge strane sučeljavanja, gdje se kao rezultat pojavljuje dobit ili gubitak prije poreza, a potom, nakon odbitka poreza na dobit, kao dobit ili gubitak nakon poreza. Klasifikacija prihoda i rashoda dodatno je analitički razrađena u podskupine i vrste prihoda i rashoda. Bitna karakteristika računa dobiti i gubitka jest da su u njemu prikazani rashodi klasificirani po prirodnim vrstama troškova, što predstavlja ograničavajući faktor za dio financijskih analiza i interpretaciju njihova rezultata. Širi model računa dobiti i gubitka obuhvaća još i prihode i rashode od udjela u dobiti i gubitku od društava s povezanim sudjelujućim interesom, odnosno od zajedničkih pothvata.

\subsection{Nefinancijske informacije i pokazatelji}

Upravljanje rizicima poslovanja, pored financijskih informacija i pokazatelja, podrazumijeva i korištenje nefinancijskih informacija i pokazatelja. Za razliku od financijskih, ove informacije i pokazatelji ne moraju uvijek biti u kvantificiranom obliku. Nefinancijski pokazatelji mogu biti i kvalitativne, a ne samo kvantitativne mjere. $U$ tom je smislu potrebno pratiti trend kretanja određenog pokazatelja koji ne mora nužno biti izražen u apsolutnim i relativnim brojevima (Grupa autora, redaktor Lajoš, 2008. str. 353). Kada je riječ o nefinancijskim informacijama, specifičnost istraživanja ogleda se u činjenici da se analitički 
promatraju organizacija poduzeća, tržišta nabave i prodaje, poslovni partneri i struktura prometa, asortiman i druga relevantna pitanja kao dio odluka upravljanja rizicima poslovanja. Bilješke uz financijske izvještaje sadrže i značajne nefinancijske informacije o odabranim poduzećima. Sadržajem daju prikaz elemenata organizacijske strukture i temeljnih računovodstvenih politika, analitičke prikaze i tumačenja značajnih kategorija pretpostavki poslovanja, različita poslovna priopćenja unutarnjih i vanjskih okruženja poslovnih subjekata, strategije bavljenja rizicima, nadzor i upravljanje rizicima. Značajan izvor nefinancijskih informacija čine priopćenja i informacije dobivene izravnim komunikacijama s vlasnicima i menadžmentom društava, posebno one informacije koje su se odnosile na utjecaje pandemije na tržište nabave i prodaje, organizaciju poslovanja te procjene budućih događaja od utjecaja na poslovanje u nadolazećem razdoblju. Pri tome treba uvažavati specifičnosti svakog poduzeća i ciljeve koje žele postići te voditi računa o tome da su nefinancijske informacije i pokazatelji također u funkciji ostvarivanja dugoročnih financijskih rezultata.

\section{ANALIZA FINANCIJSKIH IZVJEŠTAJA}

Sadržajno, analiza podrazumijeva ispitivanje problema. Svako ispitivanje ne mora biti i analiza, a da bi to bila, nužno je postojanje: (a) složenosti predmeta ispitivanja, (b) raščlambe složenih predmeta ispitivanja, (c) primjene određenih postupaka, odnosno metoda raščlanjivanja, (d) sintetiziranja rezultata radi formiranja zaključaka i (e) mišljenja i interpretacije. Nijedna analiza nije sama sebi svrha, već je ona sredstvo za stvaranje određenih prosudbi i pružanje informacija zainteresiranim korisnicima. „Smatra se da je zajednički cilj svake analize bilanca ocjena financijskog stanja i rentabilnosti“ (Krasulja, 1973. str. 89).

Analizu financijskih izvještaja možemo smatrati sredstvom kojim se pribavljaju informacije o financijskom stanju i uspješnosti poslovanja poduzetnika, koje teži stvaranju mišljenja o financijskom stanju i uspješnosti poslovanja proteklog razdoblja, kao i mišljenju o mogućnostima budućeg poslovanja i donošenju poslovnih odluka kojima će se kontrolirati rizici poslovanja i realizirati planirani ciljevi poslovanja. „Financijsko stanje i uspješnost poslovanja rezultat su niza pojedinačnih odluka o investicijama, poslovanju i financiranju, koje kontinuirano donosi menadžment (uprava) poduzeća. Zato se financijsko stanje u kontekstu donošenja tih odluka može promatrati kao kumulativni rezultat investicijskih i financijskih odluka, a uspješnost poslovanja pomoću neto učinka poslovanja (dobiti ili gubitka) u određenom razdoblju prema utjecaju na vlasničku glavnicu“ (Tintor, 2014, str. 42). Stoga se i analiza financijskih izvještaja primarno raspravlja s aspekta upravljanja poslovanjem i razvojem, što podrazumijeva i proces planiranja.

Povezanost analize financijskih izvještaja i poslovnih odluka može se razmatrati kao proces analiziranja i kao proces informiranja. Najprije se analizira djelotvornost poslovanja analiziranjem financijskog stanja, uspješnosti poslovanja, tokova novca i promjena na kapitalu nastalih kao posljedica poslovnih odluka i odluka o financiranju, a potom se dobiveni pokazatelji oblikuju i interpretiraju prema korisnicima informacija, za poboljšanja djelotvornosti poslovanja ili kao informacijska podloga za planiranje, poslovno odlučivanje i upravljanje poduzetnika.

Da bi ispunila očekivanja korisnika informacija, analiza financijskih izvještaja mora sustavno provesti ispitivanje složenog objekta ispitivanja. Dvije su standardne metode kojima to 
čini: (a) raščlanjivanje, da bi se utvrdio kvalitativan sustav i struktura složenog elementa, a za što je pretpostavka složenost elementa ispitivanja i (b) uspoređivanje kvantitativnih odnosa da bi se vidjela njegova razvojna tendencija, a za što je uvjet postojanje najmanje dvije veličine koje se uspoređuju. Osim standardnih u ispitivanju se koriste i posebne (specijalne) metode triju skupina: (a) metoda odnosa vrijednosti, kojom se odnos između dvaju skupina podataka iskazuje kao brojčani omjer, (b) metoda indeksnih brojeva ili metoda trenda, kojom se apsolutni brojevi iz financijskih izvještaja određene godine izjednačuju sa 100 , a potom se stavke sljedećih godina preračunavaju na osnovu prve godine kao bazne i (c) metoda standardizacije kojom se dobiveni pokazatelji uspoređuju sa standardnim ili drugim referentnim veličinama, a što predstavlja zadnju kariku u analizama financijskih izvještaja i prosudbi djelotvornosti poslovanja. „U procesu analize financijskih izvještaja moguće se koristiti čitavim nizom različitih postupaka" (Tintor, 1983, str. 137), koji su utemeljeni na raščlanjivanju i uspoređivanju.

Klasifikacija postupaka analize financijskih izvještaja kao temeljna sredstva i postupke koji se rabe $u$ analizi financijskih izvještaja podrazumijeva: (a) komparativne financijske izvještaje, odnosno postupke horizontalne analize koji nam pružaju informaciju o promjenama pozicija financijskih izvještaja tijekom nekoliko obračunskih razdoblja i uočavanje tendencija pomoću serije indeksa, (b) strukturne financijske izvještaje, odnosno postupke vertikalne analize koji nam pružaju informaciju o promjenama u strukturi financijskih izvještaja i (c) financijske pokazatelje koji nam pojedinačno ili kao skupina, sustav ili zbrojni sintetički pokazatelji pružaju temeljne informacije za poslovno odlučivanje. Za potrebe ove analize koristimo bilancu i račun dobiti i gubitka odabranih poduzeća.

\subsection{Horizontalna analiza financijskih izvještaja}

Značajan izvor financijskih informacija lako se može vidjeti ako istovrsne podatke iz financijskih izvještaja za dvije ili više godina prikažemo jedne pored drugih u odgovarajućoj tabličnoj formi. Takav prikaz financijskih izvještaja naziva se komparativnim financijskim izvještajem. Komparativni financijski izvještaji koji služe kao podloga za provedbu horizontalne analize mogu se razmatrati u kontekstu uspoređivanja. Horizontalnom analizom nastoje se uočiti tendencije i dinamika promjena pojedinih pozicija temeljnih financijskih izvještaja. „Na temelju tih promjena prosuđuje se kakva je uspješnost i sigurnost poslovanja promatranog poduzeća" (Gulin, Tušek i Žager, 2004, str. 179). Smatra se primarnim oblikom ispitivanja financijskih izvještaja jer se ispitivanje svodi na utvrđivanje apsolutne i/ili postotne razlike među istovrsnim podacima za razdoblje dvije ili više godina. Reduciranjem pozicija bilance i računa dobiti i gubitka željeli smo poboljšati preglednost podataka i olakšati provođenje postupka analize.

Komparativni prikaz nam pomaže u odgovaranju na pitanje poboljšava li se ili pogoršava poslovanje. Međutim, za korištenja i interpretacije podataka potrebni su nam određeni standardi radi prosuđivanja kvalitete podataka. Tri su takva standarda u primjeni: (1) uspješnost poslovanja poduzeća u prošlosti, (2) uspješnost poslovanja konkurentskih poduzeća iste djelatnosti i (3) prosječni pokazatelji grane djelatnosti poduzeća. Osim ocjene prošlih kretanja, komparativni prikaz nam pomaže i u procjeni budućih trendova, ali je tu potrebno biti oprezan jer se okruženje i uvjeti u kojima se poslovalo mogu vrlo lako promijeniti. 


\subsection{Vertikalna analiza financijskih izvještaja}

Vertikalna analiza je analiza financijskih izvještaja koja omogućava međusobno uspoređivanje pojedinih elemenata strukture financijskih izvještaja radi otkrivanja promjena i važnosti međusobnih odnosa pojedinih pozicija financijskih izvještaja. Uobičajena sredstva koja se rabe u vertikalnoj analizi jesu strukturni financijski izvještaji. „Strukturni financijski izvještaji koji služe kao podloga za provedbu vertikalne analize mogu se razmatrati u kontekstu raščlanjivanja. Vertikalna analiza omogućava uvid u strukturu financijskih izvještaja" (Gulin, Tušek i Žager, 2004, str. 179).

Strukturiranje se postiže tako da se odredi bazna pozicija financijskog izvještaja koja se izjednačava sa 100 , a potom se sve druge pozicije strukture izračunavaju kao postotak bazne pozicije. Strukturiranje bilance provedeno je na način da se ukupna aktiva i pasiva izjednačavaju sa 100 , a potom se sve pozicije aktive odnosno pasive izračunavaju kao postotak ukupne aktive ili pasive. Slično je i sa strukturiranjem računa dobiti i gubitka. Ukupni se prihod izjednačava sa 100 , a potom se sve pozicije računa dobiti i gubitka izračunavaju kao postotak od ukupnog prihoda. Prilikom strukturiranja bilance i računa dobiti i gubitka korištene su reducirane pozicije financijskih izvještaja kako bi se olakšalo provođenje postupka analize te postigla veću preglednost i usporedivost podataka.

\subsection{Pojedinačni i skupni pokazatelji}

Najznačajniji pojedinačni i skupni pokazatelji financijske analize su: pokazatelji likvidnosti, pokazatelji zaduženosti, pokazatelji aktivnosti, pokazatelji ekonomičnosti, pokazatelji profitabilnosti i pokazatelji investiranja. Jedan od primarnih zadataka menadžmenta jest osiguranje likvidnosti i sigurnosti poduzeća. Najčešći pokazatelji likvidnosti jesu koeficijent tekuće likvidnosti, koeficijent ubrzane likvidnosti i koeficijent financijske stabilnosti. Upravljanje rizicima poslovanja ima posebne zahtjeve po tim pitanjima. Naime, u praksi su odluke o pitanjima likvidnosti ponekad suprotstavljene zahtjevima sigurnosti i obrnuto. Opredjeljenje menadžera ovisit će o ukupnim okolnostima i okruženju u kojem treba donositi odluke o tim pitanjima. Zaduženost podrazumijeva da se poslovanje vodi posuđenim novcem. Najčešći pokazatelji zaduženosti su koeficijent zaduženosti, koeficijent vlastitog financiranja, koeficijent financiranja i pokriće troškova kamata. Temeljno je pravilo ako je stopa profitabilnosti veća od kamatne stope, poduzetnik će imati koristi od zaduživanja. Međutim, svako smanjenje stope profitabilnosti sugerira poduzetniku da bi, ako ima dovoljno novca, trebalo vratiti pozajmice i smanjiti stupanj zaduženosti. Pokazatelje aktivnosti mjerimo koeficijentom obrta ukupne imovine, koeficijentom obrta kratkotrajne imovine, koeficijentom obrta potraživanja i koeficijentom obrta zaliha. Analiza aktivnosti interesantna je kratkoročnim kreditorima, bankama ili dobavljačima potencijalnim partnerima jer daje odgovore na sposobnost poduzetnika da generira dovoljno obrtnih sredstava (radnog kapitala) za tekuće poslovanje i redovito plaćanje tekućih obveza. Radni kapital predstavlja višak tekuće imovine iznad tekućih obveza poduzetnika. Kvaliteta radnog kapitala mjeri se (a) strukturom kratkotrajne imovine i (b) vremenom naplate potraživanja, odnosno time koliko je potrebno da se nenovčani oblici tekuće imovine pretvore u novac. Ekonomičnost poslovanja pokazuje koliko svaka jedinica rashoda generira ostvareni veći prihod. Prema tome, upućuje na odnos prihoda i rashoda, odnosno pokazuje koliko se prihoda ostvari na svaku jedinicu rashoda. Najčešći pokazatelji ekonomičnosti jesu: eko- 
nomičnost ukupnog poslovanja, ekonomičnost poslovanja i ekonomičnost financiranja. Koeficijenti ekonomičnosti uvijek bi trebali biti veći od 1 jer samo takav odnos pokazuje da su na svaku jedinicu rashoda ostvareni veći prihodi. Profitabilnost pokazuje efikasnost poslovanja poduzetnika. Najvažniji pokazatelji su: marža profita koja pokazuje efikasnost poslovanja prije nego što se plati kamata na angažirane pozajmice, potom rentabilnost imovine koja pokazuje efikasnost korištenja ukupnog kapitala te rentabilnost kapitala koja pokazuje efikasnost korištenja vlastitog kapitala. Pokazatelji investiranja pokazuju koliko je novčanih jedinica dobiti ostvareno po dionici (udjelu), odnosno kolika je dividenda po dionici te kakav je odnos cijene i dobiti po dionici.

\subsection{Sustavi i sintetički pokazatelji}

Pojedinačni pokazatelji odnose se na pojedine segmente poslovanja. Stoga je, bez obzira na njihov broj, ograničeno njihovo korištenje radi zaključivanja o cjelini. Na određeni način to se odnosi i na pojedine skupne pokazatelje. Zbog toga se za sagledavanje cjeline koriste različiti složeni pokazatelji. „Pod sustavom ili sistemom pokazatelja podrazumijeva se izbor odgovarajućih pokazatelja, odgovarajući način njihova povezivanja ili odgovarajuća zavisnost i sveukupna zavisnost pojedinih pokazatelja i njihovog povezivanja s ciljem"(Tintor, 1983, str. 124). Najčešće koristimo dva složena sustava pokazatelja, Du Pontov sustav analitičkih pokazatelja i Altmanov Z-score sintetičkim pokazateljem financijske sigurnosti.

Du Pontov sustav pokazatelja nastao je kao potreba sagledavanja cjeline problema i koristi se prvenstveno za potrebe planiranja poslovanja, poslovnog odlučivanja i razvoja poduzetnika. On odražava najviši cilj rada i poslovanja poduzetnika. Za poduzetnike se kao najvažniji pokazatelj stanja, poslovanja i opravdanosti ulaganja ističe rentabilnost ukupne imovine. Izračun se temelji na umnošku marže profita (neto dobit + kamate / poslovni prihodi) i koeficijenta obrta ukupne imovine (poslovni prihodi / ukupna imovina). Shematski se sustav najčešće prikazuje u piramidnom obliku, tako da je na vrhu piramide prikazana rentabilnost ukupne imovine kao cilj istraživanja.

Za razliku od prethodnog pokazatelja koji upućuje na sveukupnu rentabilnost, odnosno uspjeh poslovanja, Altmanov Z-score indeks najpoznatiji je model predviđanja neuspjeha poslovanja i mogućnosti stečaja. U svojim istraživanjima koji su mu poslužili za predviđanje neuspjeha i stečaja poduzeća, Altman je koristio veći broj omjera različitih kategorija bilance i računa dobiti i gubitka koji su mu poslužili za predviđanje neuspjeha poslovanja poduzeća. Glavni mu je cilj predviđanje stečaja poduzeća u roku od jedne ili dvije godine. Altmanova formula za izračun Z-score indeksa jest zbrojni pokazatelj koji se izračunava primjenom formule $Z=1,2 \times X 1+1,4 \times X 2+3,3 \times X 3+0,6 \times X 4+1,0 \times X 5$, a namijenjena je prvenstveno proizvodnim poduzećima. Postoje i drugi sustavi i sintetički pokazatelji poput Kralicekovog DF pokazatelja, koji je sličnim postupkom analize razvio model za identificiranje krize u poduzeću. Međutim, s obzirom na to da je predmetom našeg istraživanja upravljanje rizicima poslovanja proizvodnih poduzeća, opredijelili smo se za Altmanov Z-score indeks kao model mjerenja uspješnosti poslovanja. 


\section{REZULTATI ISTRAŽIVANJA}

Istraživanje je provedeno financijskom analizom i analizom nefinancijskih informacija i podataka, dobivenih od vlasnika i menadžera odabranih poduzeća. Tijekom istraživanja korištene su analitičke metode i alati te studije slučaja. U nastavku sustavno prezentiramo financijske podatke i pokazatelje koji su činili osnovu za proaktivno upravljanje rizicima. Rizici kojima je posebno posvećena pažnja su rizici ponude i potražnje, odnosno prodaje i kupnje, povezani s ograničenjima uvedenim tijekom globalne pandemije. Isto tako, posebno smo se posvetili pitanjima organizacije i odlukama menadžera, što čini osnovu racionalnog poslovanja u svim, a posebno u uvjetima izvanrednih kriza kao što je to slučaj s globalnom pandemijom.

\subsection{Horizontalna i vertikalna analiza}

Horizontalnom i vertikalnom analizom financijskih izvještaja, točnije bilanci i računa dobiti i gubitka, nastojali smo jednostavnijim prikazom ukazati na razlike u financijskom stanju i rezultatima poslovanja odabranih poduzeća u godini prije i godini tijekom globalne pandemije. Prikazani podaci istovremeno pokazuju ostvarene rezultate u tim godinama poslovanja, ali i način na koji se upravljalo rizicima poslovanja odabranih poduzeća. Radi jednostavnosti i bolje preglednosti temeljnih podataka i informacija, u istoj su tablici istovremeno provedeni postupci horizontalne i vertikalne analize financijskih podataka, zasebno podaci o financijskom stanju, odnosno bilančni podaci, od podataka o rezultatima poslovanja prema računu dobiti i gubitka.

\subsubsection{Financijska analiza poduzeća „A“}

Tablica 1. Komparativna i strukturna bilanca

\begin{tabular}{|c|c|c|c|c|c|}
\hline OPIS & 2019. & $\%$ & 2020. & $\%$ & Index \\
\hline 1 & 2 & 3 & 4 & 5 & $6(4 / 2)$ \\
\hline A. DUGOTRAJNA IMOVINA & 314.651 .684 & 35 & 329.772.007 & 30 & 105 \\
\hline 1. Nematerijalna imovina & 8.008 .136 & 1 & 9.746 .698 & 1 & 123 \\
\hline 2. Materijalna imovina & 306.643 .548 & 34 & 320.025 .309 & 29 & 104 \\
\hline 3. Biološka imovina & 380.033 & 0 & 380.033 & 0 & 100 \\
\hline 4. Financijska imovina & 0 & 0 & 0 & 0 & - \\
\hline 5. Potraživanja & 0 & 0 & 0 & 0 & - \\
\hline B. KRATKOTRAJNA IMOVINA & 579.752 .234 & 65 & 790.959 .761 & 70 & 136 \\
\hline 1. Novac & 78.758 .014 & 9 & 348.771993 & 31 & 442 \\
\hline 2.Financijska imovina & 158.957 .605 & 19 & 140.382 .840 & 13 & 88 \\
\hline 3. Potraživanja & 24.164 .028 & 3 & 38.899 .186 & 3 & 163 \\
\hline 4. Zalihe & 317.872 .587 & 36 & 262.905 .742 & 23 & 83 \\
\hline C. AVR & 697.587 & 0 & 686.777 & 0 & 98 \\
\hline
\end{tabular}




\begin{tabular}{|l|r|r|r|r|r|}
\hline \multicolumn{1}{|c|}{ OPIS } & \multicolumn{1}{c|}{$\mathbf{2 0 1 9 .}$} & \multicolumn{1}{c|}{$\%$} & \multicolumn{1}{c|}{$\mathbf{2 0 2 0}$} & \multicolumn{1}{c|}{$\%$} & Index \\
\hline \multicolumn{1}{|c|}{1} & \multicolumn{1}{c|}{2} & \multicolumn{1}{c|}{3} & \multicolumn{1}{c|}{4} & \multicolumn{1}{c|}{5} & $6(4 / 2)$ \\
\hline D. UKUPNO AKTIVA & $\mathbf{8 9 5 . 1 0 1 . 5 0 5}$ & $\mathbf{1 0 0}$ & $\mathbf{1 . 1 2 1 . 4 1 8 . 5 4 5}$ & $\mathbf{1 0 0}$ & $\mathbf{1 2 5}$ \\
\hline A. KAPITAL I REZERVE & $\mathbf{8 7 1 . 4 4 1 . 6 4 7}$ & $\mathbf{9 7}$ & $\mathbf{1 . 0 2 9 . 8 9 0 . 3 4 9}$ & $\mathbf{9 2}$ & $\mathbf{1 1 8}$ \\
\hline 1. Upisani & 7.521 .000 & 1 & 7.521 .000 & 0 & 100 \\
\hline 2. Rezerve & 5.788 .084 & 0 & 4.191 .227 & 0 & 72 \\
\hline 3. Zadržani & 780.259 .623 & 87 & 747.307 .465 & 67 & 96 \\
\hline 4. Dobit razdoblja & 81.515 .073 & 9 & 270.870 .657 & 24 & 330 \\
\hline B. REZERVIRANJA & $\mathbf{0}$ & $\mathbf{0}$ & $\mathbf{0}$ & $\mathbf{0}$ & - \\
\hline C. DUGOROČNE OBVEZE & $\mathbf{0}$ & $\mathbf{0}$ & $\mathbf{0}$ & $\mathbf{0}$ & - \\
\hline D. KRATKOROČNE OBVEZE & $\mathbf{2 3 . 5 3 1 . 6 2 3}$ & $\mathbf{3}$ & $\mathbf{9 0 . 6 8 0 . 9 9 9}$ & $\mathbf{8}$ & $\mathbf{3 7 9}$ \\
\hline E. PVR & $\mathbf{1 2 8 . 2 3 5}$ & $\mathbf{0}$ & $\mathbf{8 4 7 . 1 9 7}$ & $\mathbf{0}$ & $\mathbf{6 6 2}$ \\
\hline F. UKUPNO PASIVA & $\mathbf{8 9 5 . 1 0 1 . 5 0 5}$ & $\mathbf{1 0 0}$ & $\mathbf{1 . 1 2 1 . 4 1 8 . 5 4 5}$ & $\mathbf{1 0 0}$ & $\mathbf{1 2 5}$ \\
\hline
\end{tabular}

Izvor: Rad autora

Tablica 2. Komparativni i strukturni račun dobiti i gubitka

\begin{tabular}{|c|c|c|c|c|c|}
\hline OPIS & 2019. & $\%$ & 2020. & $\%$ & Index \\
\hline 1 & 2 & 3 & 4 & 5 & $6(4 / 2)$ \\
\hline I. POSLOVNI PRIHODI & 365.939 .944 & 97 & 844.739 .579 & 99 & 231 \\
\hline II. POSLOVNI RASHODI & 275.530 .585 & 73 & 480.887 .783 & 57 & 174 \\
\hline 1. Promjena vrijednosti zaliha & -61.054 .850 & -16 & 44.893 .048 & 5 & 5 \\
\hline 2. Materijalni troškovi & 119.023.960 & 31 & 187.533.871 & 22 & 157 \\
\hline - troškovi sirovina i materijala & 92.450 .462 & 24 & 128.097 .666 & 15 & 15 \\
\hline - troškovi prodane robe & 3.541 .040 & 1 & 5.560 .111 & 1 & 2 \\
\hline - ostali vanjski troškovi & 23.032 .458 & 6 & 53.886 .094 & 6 & 6 \\
\hline 3. Troškovi osoblja & 139.941.372 & 37 & 168.867 .823 & 20 & 121 \\
\hline - neto plaće i nadnice & 91.392 .788 & 24 & 108.273 .460 & 13 & 12 \\
\hline $\begin{array}{l}\text { - troškovi poreza i doprinosa iz } \\
\text { plaća }\end{array}$ & 31.730 .744 & 8 & 39.575 .481 & 5 & 5 \\
\hline - doprinosi na plaće & 16.817 .840 & 5 & 21.018 .882 & 2 & 2 \\
\hline 4. Amortizacija & 41.717.820 & 11 & 40.489.716 & 95 & 95 \\
\hline 5. Ostali troškovi & 34.480 .267 & 9 & 37.164 .424 & 108 & 108 \\
\hline III. FINANCIJSKI PRIHODI & 12.011 .059 & 3 & 6.714 .579 & 1 & 56 \\
\hline 1. Kamate & 2.074 .506 & 0 & 1.154 .987 & 0 & 57 \\
\hline 2. Tečajne razlike & 9.936 .553 & 3 & 5.559 .592 & 1 & 57 \\
\hline IV. FINANCIJSKI RASHODI & 6.691 .576 & 2 & 39.639 .063 & 5 & 628 \\
\hline 1. Kamata i sl. & 169 & 0 & 511 & 0 & 303 \\
\hline 2. Tečajne razlike i sl. & 6.691 .407 & 2 & 39.638 .552 & 5 & 60 \\
\hline
\end{tabular}




\begin{tabular}{|l|c|r|r|r|r|}
\hline \multicolumn{1}{|c|}{ OPIS } & \multicolumn{1}{|c|}{$\mathbf{2 0 1 9 .}$} & \multicolumn{1}{c|}{$\%$} & \multicolumn{1}{c|}{$\mathbf{2 0 2 0}$} & \multicolumn{1}{c|}{$\%$} & \multicolumn{1}{c|}{ Index } \\
\hline \multicolumn{1}{|c|}{1} & \multicolumn{1}{c|}{2} & \multicolumn{1}{c|}{3} & \multicolumn{1}{c|}{4} & \multicolumn{1}{c|}{5} & $6(4 / 2)$ \\
\hline V. UKUPNI PRIHODI & $\mathbf{3 7 7 . 9 5 1 . 0 0 3}$ & $\mathbf{1 0 0}$ & $\mathbf{8 5 1 . 4 5 4 . 3 3 8}$ & $\mathbf{1 0 0}$ & $\mathbf{2 2 5}$ \\
\hline VI. UKUPNI RASHODI & $\mathbf{2 8 2 . 2 2 2 . 1 6 1}$ & $\mathbf{7 5}$ & $\mathbf{5 2 0 . 5 2 6 . 8 4 6}$ & $\mathbf{6 1}$ & $\mathbf{1 8 5}$ \\
\hline $\begin{array}{l}\text { VII. DOBIT/GUBITAK PRIJE } \\
\text { OPOREZIVANJA }\end{array}$ & 95.728 .842 & 25 & 330.927 .492 & 39 & 344 \\
\hline VIII. POREZ NA DOBIT & 17.855 .902 & 5 & 60.056 .835 & 7 & 333 \\
\hline IX. DOBIT ILI GUBITAK RAZDOBLJA & $\mathbf{7 7 . 8 7 2 . 9 4 0}$ & $\mathbf{2 1}$ & $\mathbf{2 7 0 . 8 7 0 . 6 5 7}$ & $\mathbf{3 2}$ & $\mathbf{3 4 7}$ \\
\hline
\end{tabular}

Izvor: Rad autora

\subsubsection{Financijska analiza poduzeća „B“}

Tablica 3. Komparativna i strukturna bilanca

\begin{tabular}{|c|c|c|c|c|c|}
\hline OPIS & 2019. & $\%$ & 2020. & $\%$ & Index \\
\hline 2 & 3 & 4 & 5 & 6 & 8 \\
\hline A. DUGOTRAJNA IMOVINA & 30.952 .937 & 35 & 27.466.533 & 32 & 89 \\
\hline 1. Nematerijalna imovina & 23.283 & 0 & 0 & 0 & - \\
\hline 2. Materijalna imovina & 30.871 .344 & 35 & 27.462 .669 & 32 & 89 \\
\hline 3. Financijska imovina & 0 & 0 & 0 & 0 & - \\
\hline 4. Potraživanja & 19.322 & 0 & 3.864 & 0 & 20 \\
\hline B. KRATKOTRAJNA IMOVINA & 56.999 .436 & 65 & 59.175.318 & 68 & 105 \\
\hline 1. Novac & 27.380 .094 & 31 & 29.125.712 & 33 & 106 \\
\hline 2.Financijska imovina & 23.163 & 0 & 21.675 & 0 & 96 \\
\hline 3. Potraživanja & 7.007.193 & 8 & 8.491 .757 & 10 & 121 \\
\hline 4. Zalihe & 22.588 .986 & 26 & 21.536 .174 & 25 & 95 \\
\hline C. AVR & 0 & 0 & 0 & 0 & - \\
\hline D. UKUPNO AKTIVA & 87.952.372 & 100 & 86.641 .851 & 100 & 99 \\
\hline A. KAPITAL I REZERVE & 80.718 .008 & 92 & 82.028 .516 & 95 & 102 \\
\hline 1. Upisani kapital & 40.396 .500 & 46 & 40.396 .500 & 47 & 100 \\
\hline 2. Obvezne rezerve & 2.019 .825 & 2 & 2.019 .825 & 2 & 100 \\
\hline 3. revalorizacijske rezerve & 15.538 .711 & 18 & 15.538 .711 & 18 & 100 \\
\hline 4. Zadržana dobit & 17.947 .289 & 20 & 21.157 .745 & 24 & 118 \\
\hline 5. Dobit poslovne godine & 4.815 .684 & 5 & 2.915 .735 & 3 & 61 \\
\hline B. REZERVIRANJA & 0 & 0 & 0 & 0 & 0 \\
\hline C. DUGOROČNE OBVEZE & 0 & 0 & 0 & 0 & 0 \\
\hline D. KRATKOROČNE OBVEZE & 7.231.711 & 8 & 4.613.335 & 5 & 64 \\
\hline E. PVR & 2.653 & 0 & 0 & 0 & - \\
\hline F. UKUPNO PASIVA & 87.952.372 & 100 & 86.641 .851 & 100 & 99 \\
\hline
\end{tabular}

Izvor: Rad autora 
Tablica 4. Komparativni i strukturni račun dobiti i gubitka

\begin{tabular}{|c|c|c|c|c|c|}
\hline OPIS & 2019. & $\%$ & 2020. & $\%$ & Index \\
\hline 1 & 2 & 3 & 4 & 5 & $6(4 / 2)$ \\
\hline I. POSLOVNI PRIHODI & 65.517 .644 & 100 & 61.989 .366 & 99 & 95 \\
\hline II. POSLOVNI RASHODI & 59.575 .514 & 88 & 58.695 .362 & 93 & 98 \\
\hline 1. Promjena vrijednosti zaliha & -6.259 .448 & -10 & 1.078 .341 & 2 & - \\
\hline 2. Materijalni troškovi & 37.069 .634 & 56 & 32.226 .814 & 52 & 87 \\
\hline - troškovi sirovina i materijala & 33.167 .539 & 51 & 28.404 .780 & 46 & 85 \\
\hline - troškovi prodane robe & 114.418 & 0 & 137.562 & 0 & 120 \\
\hline - ostali vanjski troškovi & 3.787 .678 & 6 & 3.684 .472 & 6 & 97 \\
\hline 3. Troškovi osoblja & 20.952 .315 & 32 & 17.616 .216 & 28 & 84 \\
\hline - neto plaće i nadnice & 13.654 .264 & 21 & 11.585 .531 & 19 & 85 \\
\hline $\begin{array}{l}\text { - troškovi poreza i doprinosa iz } \\
\text { plaća }\end{array}$ & 4.256 .036 & 6 & 3.438 .504 & 6 & 81 \\
\hline - doprinosi na plaće & 3.042 .014 & 5 & 2.592 .181 & 4 & 85 \\
\hline 4. Amortizacija & 4.227 .442 & 6 & 3.977 .350 & 6 & 94 \\
\hline 5. Ostali troškovi & 3.336 .948 & 5 & 3.564.354 & 6 & 106 \\
\hline 6. Vrijednosno usklađivanje & 107.935 & 0 & 129.960 & 0 & 121 \\
\hline 7. Rezerviranja & 0 & 0 & 0 & 0 & - \\
\hline 8. Ostali poslovni rashodi & 140.689 & 0 & 102.327 & 0 & 80 \\
\hline II. FINANCIJSKI PRIHODI & 187.381 & 0 & 528.146 & 1 & 282 \\
\hline 1. Kamate & 31.567 & 0 & 7.962 & 0 & 25 \\
\hline 2. Tečajne razlike & 155.814 & 0 & 520.164 & 1 & 333 \\
\hline IV. FINANCIJSKI RASHODI & 167.814 & 0 & 201.362 & 0 & 120 \\
\hline 1. Kamate & 8.181 & 0 & 272 & 0 & 3 \\
\hline 2. Tečajne razlike & 159.634 & 0 & 201.090 & 0 & 126 \\
\hline V. UKUPNI PRIHODI & 65.705 .025 & 100 & 62.517 .512 & 100 & 95 \\
\hline VI. UKUPNI RASHODI & 59.743 .328 & 91 & 58.896 .724 & 94 & 99 \\
\hline $\begin{array}{l}\text { VII. DOBIT/GUBITAK PRIJE } \\
\text { OPOREZIVANJA }\end{array}$ & 5.961 .697 & 9 & 3.620 .788 & 6 & 61 \\
\hline VIII. POREZ NA DOBIT & 1.146 .014 & 2 & 705.053 & 1 & 62 \\
\hline IX. DOBIT ILI GUBITAK RAZDOBLJA & 4.815 .683 & 7 & 2.915 .735 & 5 & 61 \\
\hline
\end{tabular}

Izvor: Rad autora 


\subsubsection{Financijska analiza poduzeća „C"}

Tablica 5. Komparativna i strukturna bilanca

\begin{tabular}{|c|c|c|c|c|c|}
\hline OPIS & 2019. & $\%$ & 2020. & $\%$ & Index \\
\hline 2 & 3 & 6 & 5 & 6 & $8(5 / 3)$ \\
\hline A. DUGOTRAJNA IMOVINA & 14.086 .588 & 68 & 14.064 .418 & 60 & 100 \\
\hline 1. Nematerijalna imovina & 1.065 .056 & 5 & 1.863 .223 & 8 & 175 \\
\hline 2. Materijalna imovina & 12.985 .472 & 63 & 12.201.193 & 52 & 94 \\
\hline 3. Financijska imovina & 0 & 0 & 0 & 0 & - \\
\hline 4. Potraživanja & 36.061 & 0 & 0 & 0 & 106 \\
\hline B. KRATKOTRAJNA IMOVINA & 6.563 .334 & 32 & 9.461 .574 & 40 & 144 \\
\hline 1. Novac & 384.537 & 2 & 946.027 & 4 & 246 \\
\hline 2. Financijska imovina & 246.705 & 1 & 481.828 & 2 & 201 \\
\hline 3. Potraživanja & 4.143.337 & 20 & 5.610 .896 & 24 & 136 \\
\hline 4. Zalihe & 1.788 .755 & 9 & 2.422 .824 & 10 & 135 \\
\hline C. AVR & 0 & 0 & 0 & 0 & - \\
\hline D. UKUPNO AKTIVA & 20.649 .923 & 100 & 23.525 .992 & 100 & 114 \\
\hline A. KAPITAL I REZERVE & 6.068 .461 & 29 & 6.068 .035 & 26 & 100 \\
\hline 1. Upisani kapital & 1.170 .700 & 6 & 1.170 .700 & 5 & 100 \\
\hline 2. Rezerve & 2.264.101 & 11 & 1.681.152 & 7 & 74 \\
\hline 3. Zadržana dobit & 2.130 .546 & 10 & 2.633 .660 & 11 & 124 \\
\hline 4. Dobit poslovne godine & 503.114 & 2 & 582.524 & 2 & 116 \\
\hline B. REZERVIRANJA & 0 & 0 & 679.726 & 3 & - \\
\hline C. DUGOROČNE OBVEZE & 10.933 .486 & 53 & 12.461.591 & 53 & 113 \\
\hline D. KRATKOROČNE OBVEZE & 3.647 .976 & 18 & 4.316.640 & 18 & 118 \\
\hline E. PVR & 0 & 0 & 0 & 0 & - \\
\hline F. UKUPNO PASIVA & 20.649.923 & 100 & 23.525 .992 & 100 & 114 \\
\hline
\end{tabular}

Izvor: Rad autora 
Tablica 6. Komparativni i strukturni račun dobiti i gubitka

\begin{tabular}{|c|c|c|c|c|c|}
\hline OPIS & 2019. & $\%$ & 2020. & $\%$ & Index \\
\hline 1 & 2 & 3 & 4 & 5 & $6(4 / 2)$ \\
\hline I. POSLOVNI PRIHODI & 29.629.547 & 100 & 28.456 .162 & 100 & 96 \\
\hline II. POSLOVNI RASHODI & 28.505 .015 & 96 & 27.399.245 & 96 & 117 \\
\hline 1. Promjena vrijednosti zaliha & 0 & 0 & 0 & 0 & 0 \\
\hline 2. Materijalni troškovi & 20.483.399 & 69 & 18.023.922 & 74 & 96 \\
\hline - troškovi sirovina i materijala & 1.788 .620 & 6 & 312.055 & 1 & 17 \\
\hline - troškovi prodane robe & 14.405 .823 & 49 & 12.545 .198 & 44 & 109 \\
\hline - ostali vanjski troškovi & 4.288 .956 & 14 & 5.166 .669 & 18 & 120 \\
\hline 3. Troškovi osoblja & 3.675 .313 & 12 & 4.217.569 & 15 & 115 \\
\hline - neto plaće i nadnice & 2.450 .906 & 8 & 2.755 .526 & 10 & 112 \\
\hline $\begin{array}{l}\text { - troškovi poreza i doprinosa iz } \\
\text { plaća }\end{array}$ & 838.543 & 3 & 980.996 & 3 & 117 \\
\hline - doprinosi na plaće & 385.864 & 1 & 481.047 & 2 & 125 \\
\hline 4. Amortizacija & 2.543 .560 & 9 & 3.238 .421 & 11 & 127 \\
\hline 5. Ostali troškovi & 1.802 .743 & 6 & 1.239 .607 & 4 & 69 \\
\hline 6. Vrijednosno usklađivanje & 0 & 0 & 0 & 0 & 0 \\
\hline 7. Rezerviranja & 0 & 0 & 679.726 & 2 & - \\
\hline 8. Ostali poslovni rashodi & 0 & 0 & 0 & 0 & 0 \\
\hline II. FINANCIJSKI PRIHODI & 12.105 & 0 & 43.613 & 0 & 367 \\
\hline 1. Kamate & 1.417 & 0 & 2.299 & 0 & 157 \\
\hline 2. Tečajne razlike & 10.688 & 0 & 41.314 & 0 & 373 \\
\hline 3.Ostali financijski prihodi & 0 & 0 & 0 & 0 & 0 \\
\hline IV. FINANCIJSKI RASHODI & 514.770 & 2 & 455.208 & 2 & 88 \\
\hline 1. Kamata & 356.927 & 2 & 363.211 & 2 & 102 \\
\hline 2. Tečajne razlike & 136.613 & 0 & 91.997 & 0 & 67 \\
\hline 3. Ostali financijski rashodi & 21.230 & 0 & 0 & 0 & - \\
\hline IX. UKUPNI PRIHODI & 29.641 .652 & 100 & 28.499 .775 & 100 & 96 \\
\hline X. UKUPNI RASHODI & 29.019.786 & 98 & 27.854 .453 & 98 & 96 \\
\hline $\begin{array}{l}\text { XI. DOBIT/GUBITAK PRIJE } \\
\text { OPOREZIVANJA }\end{array}$ & 621.866 & 2 & 645.322 & 2 & 98 \\
\hline XII. POREZ NA DOBIT & 150.740 & 0.4 & 62.799 & 0,2 & 40 \\
\hline $\begin{array}{l}\text { XIII. DOBIT ILI GUBITAK } \\
\text { RAZDOBLJA }\end{array}$ & 471.126 & 1,6 & 582.523 & 1,8 & 124 \\
\hline
\end{tabular}

Izvor: Rad autora 
Dobiveni rezultati promjenom horizontalne i vertikalne analize bilanci i računa dobiti i gubitka odabranih poduzeća zaslužuju pozitivne komentare. Naime, u okruženju u kojem je većina poduzeća pripadajuće djelatnosti poslovala s gubitkom, sva tri odabrana metaloprerađivačka poduzeća su u uvjetima globalne pandemije ostvarila pozitivno poslovanje. Štoviše, poduzeće „A“ ostvarilo je značajno povećanje prihoda i dobiti, dok poduzeća „B“ i „C“ bilježe pad ukupnih prihoda za oko 4-5 \%, ali unatoč tome ostvaruju pozitivno poslovanje. Da podsjetimo, cilj istraživanja bio je utvrditi kako su poslovala odabrana poduzeća u pandemijskoj godini, s kojim su se dodatnim rizicima poslovanja susretala u toj godini te na koji je način menadžment upravljao rizicima poslovanja odabranih poduzeća.

Poduzeće „A“ u pandemijskoj je godini ostvarilo izvanredne rezultate. Međutim, navedeno poduzeće je u dugogodišnjem razdoblju poslovanja imalo neprekinuti trend visokog rasta prihoda i dobiti i jačanja financijskog stanja, osim u pretpandemijskoj godini, kada je unatoč dobrim financijskim rezultatima ostvarilo lošije rezultate promatrane kroz prosječno višegodišnje razdoblje poslovanja. Glavni uzrok toga bile su političko-ekonomske i administrativne promjene u SAD-u kao glavnom tržištu. U pandemijskoj godini došlo je do pozitivnih promjene poslovanja s SAD-om, pa je to i rezultiralo rastom prometa od preko $150 \%$. Financijski promatrano, ukupni prihodi su povećani za $130 \%$, što je uz rast rashoda za oko $74 \%$ rezultiralo porastom dobiti za $244 \%$, pri čemu je dobit prije poreza iznosila 39 \% ukupnih prihoda. Ovakvi poslovni rezultati imali su znatan utjecaj na ukupno financijsko stanje poduzeća, još kvalitetniju bilančnu strukturu i značajno povećanje radnog kapitala. Povećane su sve vrste imovine, a upisani i zarađeni kapital predstavljali su izvor 92 \% ukupne imovine, dok su ostatak izvora predstavljale kratkoročne obveze. Ovako visok udio kapitala posljedica je višegodišnjeg zadržavanja dobiti kojom se financiralo razvoj i tekuće poslovanje, bez dugoročnih kredita.

Dobri rezultati poslovanja poduzeća „A“ ne znače da tijekom pandemije nisu, osim redovnih, postojali i izvanredni poslovni rizici. Ključni rizici poslovanja nisi bili problemi financiranja tekućeg poslovanja niti investicija s obzirom na to da je nivo proizvodne tehnologije i opreme dostigao razinu europske i svjetske tehnologije, već su to bili sljedeći rizici poslovanja: (a) povratak na izgubljena tržišta, (b) otvaranje novih tržišta, (c) rješavanje pitanja nabave materijala s obzirom na brzorastuću proizvodnju i prodaju i (4) organizacija poslovanja. Menadžment je ovim pitanjima pristupio na način da je za povratak na izgubljena tržišta povećao suradnju s već postojećim kanalima prodaje. Otvaranju novih tržišta pristupilo se kao jednom od strateških ciljeva poduzeća jer je restrikcija američkog tržišta nametnula potrebu otvaranja novih inozemnih tržišta i distribuciju rizika plasmana proizvoda te uvođenja novih proizvoda za potrebe tih tržišta. U pandemijskoj godini poslovanja, kao rezultat već spomenutih ograničenja, pojavio se problem sirovina za sve prerađivačke industrije. Razlog tome bio je u činjenici da su neka poduzeća prestala poslovati, neka su ozbiljno smanjila opseg poslovanja, a u oba slučaja se dodatno javljao i problem transporta sirovina. U slučaju poduzeća „A“ zastoj američkog tržišta u pretpandemijskoj godini pogodovao je raspolaganjem dovoljnih zaliha sirovina, poluproizvoda i gotovih proizvoda s kojima je zadovoljena potreba tržišta i dobiveno vrijeme za osiguranje novih sirovinskih resursa. Kao trajniji problem s kojim se računa već u ovoj godini poslovanja jest činjenica visokog rasta cijena sirovina, što će se u budućem razdoblju pojaviti kao novi rizik u poslovanju poduzeća. Konačno, ključan problem u vrijeme pandemije bilo je pitanje organizacije poslovanja, kako proizvodnog tako i administrativnog sektora. Taj je problem bio veći jer je mogućnost proizvodnje i prodaje u vrijeme pandemije znatno 
povećan. Menadžment je ovo pitanje riješio uvođenjem trosmjenskog poslovanja u proizvodnji te dvosmjenskog poslovanja u administraciji. Na taj su način osigurane puna zaposlenost, manja koncentracija ljudi i zaštita na radu od mogućnosti širenja virusa pa unatoč velikom broju zaposlenika, nije bilo ozbiljnijih širenja virusa, izostanaka s posla i prekida u poslovanju niti potreba za potporama države za zadržavanje zaposlenika.

Poduzeće „B“ također je ostvarilo pozitivno poslovanje i sigurno financijsko stanje. U ovom su poduzeću u pandemijskoj godini smanjeni promet i prihodi za oko 5 \%, što je uz nešto brži rast troškova rezultiralo smanjenom dobiti za oko $40 \%$. Međutim, unatoč tome, ostvarena dobit je značajna i čini oko 6 \% ukupnih prihoda. S ovim promjenama i dalje je bilančna struktura vrlo kvalitetna, s visokim stupnjem slobodnog radnog kapitala. Karakteristična za ovo poduzeće jest činjenica da kao ni prethodno poduzeće nema dugoročnih kredita i zaduženja te da mu oko 70 \% imovine čini kratkotrajna imovina, od čega je većina kunski i devizni novac na bankovnim računima. Uzrok smanjenog prometa isključivo leži u strukturi asortimana. Naime, po asortimanu proizvoda, ciljnu skupinu potrošača čine lokalne zajednice i cestovna poduzeća. U uvjetima globalne pandemije budžetske mogućnosti tih potrošača bile su smanjene, pa je to utjecalo na smanjenje ukupnog prometa. Rizici povezani s globalnom pandemijom slični su prethodnom poduzeću. Ovdje međutim pored problema tržišta dominira problem radne snage i organizacija. Problemu tržišta menadžment je pristupio otvaranjem novih tržišta u inozemstvu i novim proizvodima. Problem radne snage je specifičan jer zbog prirodnog odljeva radne snage konstantno se javlja problem potrebnih proizvodnih radnika, a što je u uvjetima globalne pandemije bilo nemoguće rješavati uvozom radne snage, iako iste nedostaje na domaćem tržištu rada. Stoga je organizacija proizvodnje riješena međusmjenskim radom, a organizacija administracije djelomičnim radom od kuće. S obzirom na uspješno poslovanje, poduzeće nije koristilo poticaje države za pokriće fiksnih troškova.

Poduzeće „C“ ima nešto drugačiju situaciju od prethodnih poduzeća. Ono također na godišnjoj razini u pandemijskoj godini ostvaruje manji pad prometa i ukupnih prihoda. Prihodi su smanjeni za oko 4 \%, što je uz sporiji rast troškova rezultiralo rastom dobiti na približno istoj razini kao i u pretpandemijskoj poslovnoj godini, a zahvaljujući nižem porezu na dobit, neto dobit tekuće godine je povećana za oko 24 \% u odnosu na pretpandemijsku poslovnu godinu. Za bolje razumijevanje nastale situacije potrebno je podsjetiti da se radi o specifičnoj proizvodnji ili bolje rečeno uslužnoj obradi svih vrsta metala. Izvori sirovina, tj. metalnih ploča uglavnom su iz uvoza i manjim dijelom s domaćeg tržišta, dok je prodajno tržište pretežito domaće s trendom rasta udjela kupaca na inozemnom tržištu. Dobar dio kupaca su proizvođači komponenti ili dijelova, čiji su finalni proizvodi namijenjeni za ugradnju u razne vrste opreme, poljoprivredne strojeve, automobilsku industriju, građevinarstvo i sl. Svi ti krajnji potrošači u vrijeme globalne pandemije imaju poremećaje u proizvodnji, pad potrošnje, pa čak i stečajeve. Uzroci njihovih poslovnih poremećaja uvjetovani su i činjenicom da su mnoge potrebne sirovine dobavljane iz inozemstva pa je redovitost snabdijevanja bila ugrožena ne samo smanjenom proizvodnjom kod dobavljača, nego i problemima transporta u vrijeme globalnog ograničavanja kretanja ljudi, transporta, pa čak i financijskih transakcija, a došlo je i do značajnog rasta cijena sirovina, na paritetu čega su se formirale nove cijene finalnih proizvoda. Zbog toga se ovo poduzeće početkom pandemijske godine susreće s višestrukim šokovima: šokom ponude, šokom potražnje, šokom naplate potraživanja, neizvjesnosti budućih događaja i nepripremljenosti menadžmenta za novonastalu kriznu situaciju poslovanja. Gubici nastali 
u tom periodu djelomično su sanirani državnim poticajima na ime održavanja zaposlenosti. Međutim, za rješavanje nastale krizne situacije mijenja se vodeći menadžment i donosi plan restrukturiranja poslovanja i upravljanja rizicima poslovanja. Pri tome, osim promjene menadžmenta, ključni utjecaj imali su nabavka sirovina prije povećanja cijena, prijelazne zalihe sirovina i materijala, povećanje udjela uslužne obrade metala donesenog materijala, pretvaranje viška dugotrajne imovine u obrtna sredstva, poduzimanje mjera za ubrzanje naplate potraživanja, promjena dijela kanala prodaje i uspostava izravnih odnosa s kupcima u EU bez posrednika, a započelo se i s ulaganjima u nove tehnologije koje omogućuju nove i kvalitetnije usluge. Zahvaljujući tim promjenama, ovo je poduzeće u kratkom roku stvorilo prednost pred konkurencijom u mogućnosti redovitosti proizvodnje i zadovoljavanja potražnje. Uspješnim upravljanjem navedenim rizicima poslovanja poduzeće, unatoč smanjenju prihoda, uspješno završava poslovnu godinu. Štoviše, nabavkom najsuvremenijeg tipa lasera, koji omogućuje pružanje novih vrste usluga visoke potražnje i povećanja produktivnosti, očekuje se značajan rast proizvodnje, prometa i financijskog rezultata.

\subsection{Pokazatelji financijske analize}

Tablica 7. Usporedni pregled pokazatelja financijske analize

\begin{tabular}{|c|c|c|c|c|c|c|c|c|c|}
\hline \multirow[t]{2}{*}{ OPIS } & \multicolumn{3}{|c|}{ A } & \multicolumn{3}{|c|}{ B } & \multicolumn{3}{|c|}{$\mathrm{C}$} \\
\hline & 2019. & 2020. & Index & 2019. & 2020. & Index & 2019. & 2020. & Index \\
\hline \multicolumn{10}{|l|}{ Pokazatelji likvidnosti } \\
\hline Koeficijent tekuće likvidnosti & 25,34 & 8,68 & 34 & 7,88 & 16,98 & 216 & 1,78 & 2,19 & 123 \\
\hline $\begin{array}{l}\text { Koeficijent ubrzane } \\
\text { likvidnosti }\end{array}$ & 11,08 & 5,80 & 52 & 4,76 & 16,92 & 355 & 1,31 & 1,63 & 124 \\
\hline $\begin{array}{l}\text { Koeficijent trenutne } \\
\text { likvidnosti }\end{array}$ & 3,25 & 3,84 & 118 & 3,79 & 6,31 & 166 & 0,09 & 0,22 & 244 \\
\hline $\begin{array}{l}\text { Koeficijent financijske } \\
\text { stabilnosti }\end{array}$ & 0,36 & 0,32 & 89 & 0,38 & 0,33 & 87 & 0,83 & 0,76 & 93 \\
\hline \multicolumn{10}{|l|}{ Pokazatelji zaduženosti } \\
\hline Koeficijent zaduženosti & 2,63 & 8,11 & 308 & 0,08 & 0,05 & 63 & 0,71 & 0,71 & 100 \\
\hline Koeficijent samofinanciranja & 2,70 & 9,18 & 340 & 0,92 & 0,95 & 103 & 0,29 & 0,29 & 146 \\
\hline Koeficijent financiranja & 0,03 & 0,09 & 300 & 0,09 & 0,16 & 178 & 2,40 & 2,76 & 115 \\
\hline Koeficijent pokrića kamata & 15,30 & 9,35 & 0,61 & 36,69 & 18,92 & 52 & 2,39 & 2,42 & 110 \\
\hline \multicolumn{10}{|l|}{ Pokazatelji aktivnosti } \\
\hline Koeficijent obrta UI & 0,42 & 0,32 & 76 & 0,75 & 0,72 & 96 & 1,43 & 1,21 & 85 \\
\hline Koeficijent obrta KI & 0,65 & 1,08 & 166 & 1,15 & 1,06 & 92 & 4,52 & 3,01 & 67 \\
\hline $\begin{array}{l}\text { Koeficijent obrta } \\
\text { potraživanja }\end{array}$ & 57,62 & 32,00 & 56 & 9,68 & 7,86 & 81 & 7,25 & 5,24 & 72 \\
\hline Koeficijent obrta zaliha & 1,15 & 3,18 & 277 & 2,90 & 2,88 & 99 & 16,07 & 11,75 & 73 \\
\hline
\end{tabular}




\begin{tabular}{|c|c|c|c|c|c|c|c|c|c|}
\hline \multirow[t]{2}{*}{ OPIS } & \multicolumn{3}{|c|}{ A } & \multicolumn{3}{|c|}{ B } & \multicolumn{3}{|c|}{$\mathrm{C}$} \\
\hline & 2019. & 2020. & Index & 2019. & 2020. & Index & 2019. & 2020. & Index \\
\hline \multicolumn{10}{|l|}{ Pokazatelji ekonomičnosti } \\
\hline Ukupno poslovanje & 1,34 & 1,64 & 122 & 1,10 & 1,06 & 96 & 1,02 & 1,02 & 100 \\
\hline Ekonomičnost poslovanja & 3,08 & 4,51 & 146 & 1,74 & 1,92 & 110 & 1,03 & 1,04 & 101 \\
\hline Ekonomičnost financiranja & 1,80 & 0,17 & 9 & 1,12 & 2,63 & 235 & 0,03 & 0,10 & 333 \\
\hline \multicolumn{10}{|l|}{ Pokazatelji profitabilnosti } \\
\hline Marža profita (MP) \% & 21,61 & 31,87 & 147 & 9,07 & 5,79 & 64 & 2,23 & 2,26 & 101 \\
\hline EBIT (\%) & 25,37 & 38,93 & 153 & 9,08 & 5,79 & 64 & 3,08 & 3,86 & 101 \\
\hline Rentabilnost imovine (R) \% & 9,09 & 27,65 & 304 & 5,66 & 4,18 & 74 & 4.74 & 4,40 & 93 \\
\hline Rentabilnost kapitala (RK) \% & 9,32 & 26,30 & 282 & 5,96 & 3,55 & 60 & 8,29 & 9,59 & 116 \\
\hline \multicolumn{10}{|l|}{ Pokazatelji investiranja } \\
\hline $\begin{array}{l}\text { 1. EPS (neto dobit/broj } \\
\text { dionica) }\end{array}$ & - & - & - & 1.681 & 1.018 & 61 & - & - & - \\
\hline 2. DPS (isplata/broj dionica) & - & - & - & 560 & - & - & - & - & - \\
\hline 3. P/E Tržna cijena dionice & - & - & - & - & - & - & - & - & - \\
\hline
\end{tabular}

Izvor: Rad autora

U Tablici 7. prikazani su usporedni pokazatelji financijske analize za poslovnu godinu prije pandemije te pandemijsku poslovnu godinu i trend kretanja ključnih financijskih pokazatelja. Opći je dojam da je većina financijskih pokazatelja pozitivna, bez obzira na činjenicu da su neki od pokazatelja u pandemijskoj godini poslovanja imali trend smanjenja. Stoga u nastavku dajemo komentar stanja i kretanja po skupinama pokazatelja, usporedno za sva tri odabrana poduzeća.

Pokazatelji likvidnosti na razini opće i ubrzane likvidnosti su zadovoljavajući kod sva tri poduzeća. Međutim, za razliku od poduzeća „A“ $\mathrm{i}$ „B“ kod kojih su pokazatelji trenutne likvidnosti iznad standardnih veličina, kod poduzeća „C“, unatoč trendu rasta, to nije slučaj. Razlog tome je u spomenutoj nabavci većih količina zaliha materijala, koji su zbog nižih nabavnih cijena od tekućih pridonijeli skrivenoj dobiti u bilanci poduzeća. Koeficijent financijske stabilnosti zadovoljavajući je kod sva tri poduzeća, što upućuje na to da su pravilnim upravljanjem rizika poslovanja pridonijeli ne samo pozitivnom rezultatu poslovanja, već i financijskoj stabilnosti poduzeća.

Pokazatelji zaduženosti kod poduzeća „A“ i „B“ upućuju na nizak stupanj zaduženosti, pri čemu niti jedno poduzeće nema dugoročnih obveza bilo koje vrste, a kratkoročne obveze se svode na tekuće obveze poslovanja. Slučaj poduzeća "C" nešto je drugačiji. U stvarnosti se radi o relativno visokoj zaduženosti s tendencijom rasta. U strukturi obveza dominiraju dugoročne obveze povezane s izgradnjom proizvodne hale i nabavke opreme u ranijem razdoblju te djelomično s nabavkom opreme čija će isporuka pretežito uslijediti u sljedećoj godini poslovanja. U strukturi dugoročnih obveza dominiraju obveze prema bankama, međutim značajne su i obveze po osnovi pozajmica vlasnika. To ne mijenja na težini obveza, međutim sastavni dio plana restrukturiranja jest pretvaranje dijela obveza prema vlasnicima u temeljni kapital, čime će se rasteretiti tekuće poslovanje i restrukturirati bilanca poduzeća. 
Pokazatelji aktivnosti upućuju na efikasnost korištenja angažiranih sredstava. Temeljno je pravilo što su koeficijenti veći, to je brži i veći obrt imovine. Upravljanje ovim rizicima svodi se na nastojanje skraćivanja svih rokova u procesu poslovanja, od proizvodnje i plasmana proizvoda, što kraćeg zadržavanja svih vrsta zaliha i što kraćih rokova naplate potraživanja. Prema dobivenim rezultatima, vidljivo je da je, osim u nekoliko iznimaka, gotovo na svim pozicijama zabilježen trend smanjivanja koeficijenata obrta imovine. To znači da je pod utjecajem rizika povezanih s globalnom pandemijom u konačnici rezultat bila smanjena efikasnost korištenja resursa. Međutim, usporedbom s drugim djelatnostima, gdje je taj trend bio izrazito lošiji, proizlazi da se upravljanjem relevantnim rizicima uspjelo osigurati niži trend smanjenja nego što je to bio opći trend u gospodarstvu.

Pokazatelji ekonomičnosti upućuju na uspješno upravljanje rizicima utjecaja na ekonomičnost poslovanja. Naime, gotovo svi pokazatelji kod sva tri poduzeća imaju pozitivan trend, odnosno povećanje ekonomičnosti poslovanja. Međutim, postoji značajna razlika u visini koeficijenata koji odražavaju stanje ekonomičnosti poslovanja. Dok se kod poduzeća „A“ $\mathrm{i}$ „B“ ostvaruje visoki stupanj ekonomičnosti poslovanja, kod poduzeća „C“ riječ je o relativno niskoj ekonomičnosti poslovanja. To upućuje na to da investicijska ulaganja koja su prethodila pandemijskoj godini, kao i ona koja su u tijeku, još nisu optimizirala poslovanje te da povećani troškovi nisu amortizirani ekonomijom obujma i racionalizacijama povezanim s uvođenjem suvremene tehnologije.

Pokazatelji profitabilnosti su različiti po analiziranim poduzećima. Dok je u poduzeću „A“ profitabilnost značajno povećana, u poduzeću „C“ ona je zadržana na približno istoj razini s tendencijom rasta, a u poduzeću „B“ došlo je do pada produktivnosti. To je i logična posljedica u tom poduzeću jer se kod tog poduzeća u pandemijskoj godini poslovanja realno smanjio fizički opseg, kao i prihodi poslovanja. Međutim, i u ovom smo slučaju, na bazi usporedbe s kretanjem produktivnosti kod drugih industrija, spremni ustvrditi da je upravljanje rizicima od utjecaja na produktivnost bilo zadovoljavajuće te da bi u protivnom realan pad bio znatno veći.

Pokazatelji investiranja su u prikazanoj tablici samo djelomično prezentirani. Razlog tome je u činjenici da je samo jedno poduzeće dioničko društvo te da predmet naših analiza u ovom slučaju nije razmatranje interesa investitora ili kreditnih institucija. Međutim, ono što je važno naglasiti s aspekta upravljanja rizicima jest činjenica da su sva tri poduzeća svoje odluke o eventualnoj isplati dobiti odgodile do daljnjeg s tendencijom zadržavanja dobiti radi smanjenja rizika budućeg poslovanja i osiguranja vlastitih izvora financiranja rasta i razvoja.

\subsection{Sustavi pokazatelja i sintetički pokazatelji}

Prethodno prikazani pojedinačni pokazatelji odnose se na pojedine segmente poslovanja. Stoga je bez obzira na njihov broj ograničeno njihovo korištenje radi zaključivanja o cjelini. $\mathrm{Na}$ određeni način to se odnosi i na pojedine skupne pokazatelje. Zbog toga se za sagledavanje cjeline koriste različiti složeni pokazatelji. „Pod sustavom ili sistemom pokazatelja podrazumijeva se izbor odgovarajućih pokazatelja, odgovarajući način njihova povezivanja ili odgovarajuća zavisnost i sveukupna zavisnost pojedinih pokazatelja i njihovog povezivanja s ciljem“ (Tintor, 1983, str. 124). Najčešće koristimo dva složena sustava pokazatelja, Du Pontov sustav analitičkih pokazatelja i Altmanov Z-score sintetički pokazatelj financij- 
ske sigurnosti. Detalji izračuna ovih pokazatelja prikazani su i prethodnim izlaganjima pa ćemo ovdje dati prikaz dobivenih pokazatelja.

Tablica 8. Usporedni prikaz sustava pokazatelja

\begin{tabular}{|l|r|r|r|r|r|r|r|r|r|}
\hline \multirow{2}{*}{ OPIS } & \multicolumn{3}{|c|}{ A } & \multicolumn{3}{c|}{ B } & \multicolumn{3}{c|}{ C } \\
\cline { 2 - 11 } & 2019. & 2020. & Index & 2019. & 2020. & Index & 2019. & 2020. & Index \\
\hline Poduzeće „A“ & & & & & & & & & \\
\hline Altmanov Z-score indeks & 25,05 & 10,25 & 41 & 8,54 & 12,63 & 147 & 2,11 & 1,97 & 93 \\
\hline $\begin{array}{l}\text { Du Pontov sustav } \\
\text { pokazatelja }\end{array}$ & 10,66 & 29,25 & 274 & 5,18 & 3,36 & 65 & 4,02 & 3,63 & 90 \\
\hline
\end{tabular}

Izvor: Rad autora

Altmanov Z-score indeks, na temelju ponderiranog zbroja, upućuje na financijsko stanje poduzeća, pri čemu veći broj znači veću financijsku stabilnost poduzeća. Nasuprot tome, manji zbroj upućuje na moguće financijske neprilike. Prema usvojenim standardima, zbroj veći od 3 upućuje na vrlo stabilna poduzeća kod kojih nema opasnosti od stečaja, odnosno bankrota. Veličina pokazatelja između 1 i 3 predstavlja upitnu stabilnost, a ako je taj zbroj manji od 1, tada je riječ o poduzeću koje ima značajne financijske poteškoće i prijeti mu bankrot. U našem slučaju poduzeće "A“ i poduzeće „B“ imaju zbroj znatno veći od 3 , što znači da su vrlo stabilna i bez opasnosti bankrota. Poduzeće "C“ je u „sivoj zoni“ jer mu je zbroj u pandemijskoj godini poslovanja smanjen s 2,11 na 1,97, dakle, ima tendenciju smanjivanja, što upućuje na financijsku nestabilnost i moguće financijske neprilike. U tom je kontekstu značajna činjenica da je menadžment tog poduzeća uočio navedeni problem i planiranim restrukturiranjem predvidio mjere kojima će utjecati na financijsku stabilnost poduzeća.

Du Pontov sustav pokazatelja najznačajniji je pokazatelj stanja, poslovanja i opravdanosti ulaganja pa je za vlasnike, menadžment i sve druge zainteresirane strane vrlo važan. Mjeri se stupnjem rentabilnosti prema pojašnjenoj formuli izračuna. $U$ našem slučaju neupitna je rentabilnost poduzeća „A“ ne samo visinom, nego i trendom rasta. Poduzeće „B“ $\mathrm{i}$ „C imaju znatno nižu razinu rentabilnosti ukupne imovine s tendencijom smanjenja. Usporedbom s uobičajenim kamatnim stopama na kredite, ovo se uvjerenje dodatno potvrđuje jer bi za očekivati bilo da su stope rentabilnosti ukupne imovine veće od kamatnih stopa na kredite. Unatoč tome, mišljenja smo da se menadžment u sva tri poduzeća uspješno nosio s tim rizicima te svojim odlukama i rezultatima poslovanja bez gubitaka potvrdio uspješnost upravljanja rizicima poslovanja.

\section{ZAKLJUČAK}

Svaki poduzetnički projekt nosi određene rizike poslovanja, a poduzetnik bi trebao koristeći svoja iskustva, znanja, poznavanje okruženja ili pak uz pomoć suvremenih metoda procjena rizika nastojati rizik poslovanja svesti na što manju mjeru, odnosno nepredvidive negativne utjecaje pretvoriti u predvidive, kako bi mogao upravljati rizicima poslovanja. Rizik poslovanja se prvenstveno odnosi na mogućnost financijskog gubitka. Najčešće rizici 
poslovanja podrazumijevaju rizike likvidnosti i stabilnosti, zaduženosti, profitabilnosti i ekonomičnosti, investicijske rizike te nemogućnost vremenske neograničenosti poslovanja. U uvjetima globalne pandemije, uz uobičajene rizike poslovanja, javljaju se i dodatni rizici poslovanja imanentni stanju u okruženju, poput rizika ponude i potražnje, inflacije, neizvjesnosti sustava i dr.

Upravljati rizicima poslovanja znači prvenstveno identificirati rizike, procijeniti njihove utjecaje na poslovanje i poduzeti odgovarajuće mjere za rješavanje rizika poslovanja. Za to je potrebno izgraditi odgovarajući model upravljanja rizicima. Primjereno složenosti uzroka i vrste rizika moguća je primjena različitih metoda upravljanja rizicima. Međutim, bez obzira na izbor i korištene metode upravljanja rizicima, svima su zajednički nužnost poznavanja i razumijevanja problematike, poznavanje unutarnjeg i vanjskog okruženja kao izvora rizika poslovanja te korištenje analitičkih metoda istraživanja i izvještavanja o načinu upravljanja rizicima poslovanja. Posebno su važni znanje i vještine onih koji upravljaju rizicima.

Najvažniji izvor takvih informacija su financijski izvještaji poduzetnika koji pružaju informacije o financijskom stanju, uspješnosti poslovanja i promjenama u financijskom položaju poduzetnika. Međutim, financijski izvještaji izravno ne pružaju sve potrebne informacije pa za potrebe upravljanja rizicima posebno značenje ima analiza financijskih izvještaja koja pruža razne dodatne financijske informacije. Zbog toga upravljanje rizicima poslovanja, pored financijskih informacija i pokazatelja, podrazumijeva i korištenje nefinancijskih informacija i pokazatelja. To mogu biti različite informacije o organizaciji poduzeća, tržištu nabave i prodaje, poslovnim partnerima, strukturi prometa, asortimanu i drugim pitanjima važnim za upravljanje rizicima poslovanja.

Cilj je ovog rada bio istražiti utjecaj globalne pandemije na poslovanje triju odabranih poduzeća metaloprerađivačke djelatnosti, prepoznati rizike njihova poslovanja u uvjetima globalne pandemije i procijeniti u kojoj je mjeri menadžment ispunio svoju zadaću upravljanja rizicima poslovanja u uvjetima globalne pandemije. Za ocjenu uspješnosti proveli smo istraživanje analiziranjem financijskih izvještaja odabranih poduzeća u pandemijskoj godini prema prethodnoj godini poslovanja prije pojave globalne pandemije, kao i korištenjem nefinancijskih informacija dobivenih od relevantnih unutarnjih i vanjskih izvora takvih informacija.

Prema rezultatima istraživanja, cijenimo da su sva tri poduzeća, unatoč brojnim poteškoćama uvjetovanim utjecajem globalne pandemije pozitivno poslovala, a neka su čak ostvarila i značajno povećanje proizvodnje, prihoda dobiti i stabilnosti poduzeća. U dva od analiziranih poduzeća ostvaren je manji pad proizvodnje i prihoda, što nije značajnije utjecalo na njihovu profitabilnost i financijsku stabilnost. Prema financijskim pokazateljima, sva tri su poduzeća uglavnom iskazala zadovoljavajuće rezultate u okvirima standardnih pokazatelja. Stagnacija likvidnosti zabilježena je samo kod jednog poduzeća, no i za taj bi se slučaj moglo zaključiti da je bila riječ o svjesnoj prekomjernoj nabavci zaliha sirovina utemeljenoj na procjeni da će globalna pandemija utjecati na nestanak sirovina i visoki rast cijena, što se u konačnici pokazalo kao točno i kao opća pojava. Naime, s današnje pozicije gledanja i temeljem informacija iz relevantnih izvora zaključujemo da je navedena procjena bila ispravna jer je jedna od najtežih posljedica na poslovanje cijele grupacije metaloprerađivača upravo nedostatak i visoki rast cijena svih vrsta sirovina. Ostali pokazatelji financijske analize su uglavnom zadovoljavajući, s tim da postoji značajna razlika u 
visini i kvaliteti istih po svakom pojedinom poduzeću. Isto vrijedi i za sustave financijskih pokazatelja, s tim da je Altmanov Z-score indeks kod poduzeća „C" u sivoj zoni prosudbe.

Stoga, temeljem provedenih istraživanja naš je zaključak za sva tri poduzeća, mada različita i s različitim rizicima poslovanja, da je menadžment uglavnom na vrijeme prepoznao rizike poslovanja uvjetovane globalnom pandemijom i na njih pravovremeno reagirao donoseći ispravne odluke spram tržišta nabave i prodaje, poslovnih partnera, organizacije poslovanja, pa čak i krizu iskoristio kao šansu za otvaranje novih kanala prodaje, uspostavljanje novih tržišta i partnera u nabavi i prodaji te poduzeo značajne korake u organizaciji poslovanja i investiranju u nove tehnologije. Također, stečena su i značajna njihova iskustva u funkcioniranju sustava i ponašanju centara moći u uvjetima globalne pandemije. 


\title{
BUSINESS RISK MANAGEMENT OF SELECTED METAL PROCESSING COMPANIES DURING THE PANDEMIC
}

\author{
M. Sc. Željko Tintor \\ RETRA d.o.o. for auditing and business consulting \\ Lastovska 6., 10000 Zagreb, Croatia \\ Phone: +385 916159 292, e-mail: retra@zg.htnet.hr
}

\section{ABSTRACT}

The most important task of management is to make business decisions aimed at ensuring optimal business and profit, as well as future growth and development of the company. For this, it is necessary to organize a monitoring system that will, in a timely manner, identify the risks that may affect the company's operations and business decisions. Therefore, it is extremely important to pay attention to business analysis and the development of risk management systems appropriate to market and social changes. Year 2020, in addition to constant market challenges, was especially marked by the appearance of the global pandemic caused by the COVID-19 virus, which significantly affected the changes in the overall social and economic life in the world and in our country. The unemployment rate increased, while revenues, demand, supply and production decreased. In order to prevent the spread of the virus with unpredictable health and economic consequences, most countries in the world, especially the European Union, including our country, have adopted various security measures aimed at social distancing, from mild and recommended to a lockdown. Movements of citizens at the local level, and travel among cities and countries have been abolished or restricted, shops have been restricted and certain activities have been banned, while going to work has been replaced by working from home and reorganizing working hours. All this has had a negative impact on the economy, especially on tourism, hospitality, transport and trade, but also on manufacturing activities, depending on the extent to which they depend on broad, industrial or investment consumption, or local, national or international market. The metal processing industry has a long tradition and with about $20 \%$ share in the domestic product and about $25 \%$ share in exports, it is a significant driving force of the Croatian economy. Therefore, this paper is dedicated to the study of the impact of the global pandemic on the operations of selected companies in the metal processing industry in the Republic of Croatia. The paper analyzed operations of three companies, which have a common activity and business in the domestic and foreign markets, while being different in sizes and legal statuses. The problem of the research was to identify the business risks of selected companies in the conditions of the pandemic,

which was done by a comparative financial analysis in the pandemic 2020 compared to the previous 2019 before the pandemic. The aim of the research is to assess the impact of the pandemic on their business through financial indicators and business risk management models in the pandemic. The general assessment is that the negative impact of the pandemic will continue in the upcoming period, so significant attention was paid to the 
assessments of future trends and the development of risk management systems, in order to prevent future damage to the business and development of selected companies.

Keywords: business risk management, global pandemic; metal processors; financial analysis

\section{LITERATURA}

1. Broz Tominac, S. Dragija, M. Hladika, M. i Mićin, M. (2015). Upravljačko računovodstvo - studija slučajeva, Zagreb: Hrvatska zajednica računovođa i financijskih djelatnika.

2. Dražić Lutilsky, I. Gulin, D. Mamić Sačer, I. Tadijančević, S. Tušek, B. Vašiček, V. Žager, K. i Žager, L. (2010). Računovodstvo, Zagreb: Hrvatska zajednica računovođa i financijskih djelatnika.

3. Gulin, D. (2011). Upravljačko računovodstvo, Zagreb: Hrvatska zajednica računovođa i financijskih djelatnika.

4. Gulin, D., Tušek, B. i Žager, L. (2004). Poslovno planiranje, kontrola i analiza, Zagreb: Hrvatska zajednica računovođa i financijskih djelatnika.

5. Helfert, E. A. (1997). Tehnika financijske analize, Zagreb: Hrvatska zajednica računovođa i financijskih djelatnika.

6. Hladika, M. (2008). Primjena HSFI 15 - Prihodi // Primjena Hrvatskih standarda financijskog izvještavanja - s poreznim propisima / Gulin, Danimir (ur.). Zagreb: Hrvatska zajednica računovođa i financijskih djelatnika.

7. Krasulja, D. (1973). Finansijska analiza poduzeća, Beograd: Ekonomski fakultet.

8. Meigs, R. F. i Meigs, W. B. (1999). Računovodstvo - temelj poslovnog odlučivanja, Zagreb: Mate.

9. Robert, N. A. i James, S. R. (2004). Financijsko i upravljačko računovodstvo, Zagreb: RRIF.

10. Rodić, J. (1990). Teorija i analiza bilansa, Beograd: Ekonomika.

11. Tintor, J. (1983). Uvod u ekonomsku analizu poslovanja OUR-a, Zagreb: NN, Zagreb 1983.

12. Tintor, Ž. (2014). Analiza financijskih izvještaja. Zagreb: Školska knjiga.

13. Tintor, J. (1983). Uvod u ekonomsku analizu poslovanja OUR-a. Zagreb: Narodne novine.

14. Vasiljević, K. (1970). Teorija i analiza bilansa, Beograd: Savremena administracija.

15. Završni računi odabranih poduzetnika (2020). GFI, Zagreb: Fina.

16. Žager, K. Mamić Sačer, I. Sever, S. i Žager, L. (2008). Analiza financijskih izvještaja - 2. prošireno izdanje, Zagreb: Masmedia. 